\title{
CHALENGING ISSUES IN LEARNING LISTENING: A CORRELATIONAL STUDY IN UNIVERSITY LEVEL
}

\author{
Raden Rara Vivy Kusuma Ardhani \\ Senior High School 3 Yogyakarta
}

\begin{abstract}
Listening is one of the four skills that have an important role in mastering the target language, especially in the university level. This skill is very useful to help college students to do some academic activities that involve attending lectures or speeches, presenting materials or finding some resources to do their assignments. However, listening skill cannot be developed well due to some problems. Based on a research, listening problems include lack of vocabulary mastery, less understanding grammatical forms, e.g: speakers' utterances, unclear pronunciation and speed of speech, unclear contents of the passages, and physical setting including uncomfortable class; and lack of facility and background noise. The data is proven by the achievement of listening test that indicates that students who have listening problems tends to have low achievement in the class. To overcome this problem, lectures have to design specific instructional design to solve the listening problems. This paper will discuss more about listening problems and the appropriate learning strategies to solve the problems.
\end{abstract}

Key words: instructional design, listening skills, college students

\section{INTRODUCTION}

Listening is one of the fundamental skills in language learning, in addition to speaking, reading, and writing. This skill has been learned since young age. Burhan (1971:81) explained that the basic ability to listen is innate and will be developed through a learning process. The learning process will make a child has the ability to listen effectively. Early listening development provides the foundation on which a child's speech and language abilities and literacy skills are built. The early-childhood-education stage is a time to build listening skills in children. However, a child is not going to be able to build these listening skills on 
his own. It is the responsibility of the teacher in the classroom to present children with activities that help build and enhance listening skills.

The development of listening skill is related to communication ability. Communication has an important role in learning English language. There must be an interaction between at least two or more people involving a speaker and a listener. The speaker expresses her or his ideas by introducing utterances, and the listener receives the messages, keeps the utterances in memory, analyzes and identifies lexical illocutionary meaning. Communication skill is necessary to master for college student because they need to do some academic activities that involves attending lectures or speeches, presenting materials or finding some resources to do their assignments.

However, the communication skill of college students cannot develop well in some cases due to some listening skills issues or problem, such as physical and psychological aspect of the listeners. Physical factors include hearing problem. Meanwhile, psychological factors involve intelligence, interest, attitude, motivation, and readiness to learn. In addition, listening problems also include native speaker, environment, facility and teachers' teaching strategies. To overcome the challenges, lecturer should choose appropriate material that includes the basic concept of listening skill, for example: pre-listening stage, whilelistening stage and post-listening activities stage. These concepts can be applied in some learning activities such as comprehending listening texts effectively and efficiently from words, parsing, and memory processes. In each of the processes, the listeners will use some strategies including receiving the message, grouping, and centering the learning process, analyzing, cooperation with others, arranging the learning activities and practicing and reviewing their learning strategy. Those strategies are important factors in developing listening comprehension. They support the listeners in listening processes in order to get a high achievement in listening skill.

Moreover, these basic skills should be arranged based on students' interest to improve their achievement and motivation. Listening is a problematic skill to the students. If lecturers do not consider students' need and character, the learning process will not be success. Students' input data is one of the important considerations among teaching components such as materials, media, learning strategies and environment. Instructional design that is organized based on students' learning problems or character will support the development of readiness 
in learning. The learners should be ready to deal with mistakes or difficulties in listening activities. To have this willingness, inhibition of learning should be eliminated. One of the inhibitions of learning is difficulty. It is in fact impossible for everyone to know everything about a listening text. To be ready to deal with difficulties in listening activities people should have a risk-taking plan. In a listening process, someone who is ready to deal with mistakes and difficulties in learning activities are called a risk taking activity. It is related with the students' self-confidence and also their low anxiety.

Based on the description above, this paper will discuss about more issues or problems in learning listening by correlating students' problem in listening skill and their achievement in the class.

\section{DISCUSSION}

\section{Listening}

Listening is the ability to receive, comprehend and understand the message in spoken language (Yagang, 1993:1). On other words, listening is the activity of paying attention to and trying to get the meaning from the information that has been heard. According to Howatt and Dakin (1974:93) listening is the process of a person understanding the meaning of the spoken language. The aim of listening for comprehension is to get the meaning of what the listeners hear and then produce a response to show what they have understood.

Listening is an important role in mastering a target language in spoken forms. By mastering listening skills, English learners will be able to grasp the message sent by speakers and able to respond logically to what is meant by the speakers. In a listening process the listeners understand and translate the messages addressed to them.

According to Byrne (1981:42) states that listening is a process of orally grasping and decoding the signs a listener directly hears. In a listening process, a listener understands and translates the message addressed to him and gets the meaning in the listeners' mind. To conclude, the purpose of listening involves the process of hearing, understanding, evaluating, and responding to the message.

\section{Listening Skill}

Listening skill is the prosperity of a person to understand the meaning of the spoken language. Listening is the ability to identify and understand what others 
are saying. This involves understanding the speakers' accent of pronunciation, grammar, vocabulary, and grasping the meaning (Howatt and Dakin, 1974:93). Meanwhile, Widdowson (1978:60) states that listening skill is a skill to understand the spoken language of a particular sentence to be used in an interaction. This means that understanding the context of the sentence to recognize of the significance of the speaker's meaning. In addition, Brown (2001:256), as quoted from Richards (1983), says that the micro-skills of listening have the goals that can be used as testing criteria, for example: the ability of understanding speech, stress pattern, intonation, pauses, error, grammatical rules and meaning. The micro skills are useful in an effective listening comprehension and can be applied in learning listening to:

1. Recognize a particular meaning expressed in grammatical forms.

2. Infer goal using the real knowledge.

3. Detect the main ideas.

4. Generalize and use some strategies of listening such as guessing, grouping, detect the key words and taking notes.

In the process of developing listening skills, the listeners need some process that can be facilitated by functional and formal practicing. According to Krashen and Terrel (1983:19) acquisition or development of a language can take place only when people understand the message in the target language. They also write that listening is an activity to get the message and information of what is heard in the target language. Therefore, the efforts to develop listening skill include some basic knowledge such as pre-listening, while-listening, and post-listening (Cook, 2001:132). Each of the stages is explained as follows:

a) Pre-listening

Pre- listening activities help students make decisions about what to listen, and subsequently, to focus attention on meaning while listening. A purpose for listening must be established, so that students know the specific information they need to listen to or the degree of details are required. The students are expected to be able to activate their background knowledge and vocabulary mastery.

b) While-listening

The technique in this stage includes listen to a dialogue and decide where the conversation occurred, listen to a conversation and decide what the people are 
talking about. In while- listening activities, it focuses their attention on key ideas in the text such as asking the students to find how many speakers and how often they hear certain words, and how many questions they hear, etc.

c) Post-listening

This activity is to ensure the students' comprehension and retention of the message. It consists of extension and development of the listening task. Students need to evaluate the results of decisions made during a listening task. In this part, the lesson is about giving a task related to the topic to ensure the students' comprehension and retention of the message and reflection on the language of the passage, asking the students to express and develop the listening task in spoken/written forms.

\section{Listening Problem in University Level}

The discussion of listening problems in university level was taken from a research, conducted in 2007 at English Language Education Department of Sarjanawiyata Tamansiswa University, Yogyakarta, in academic year 2006/2007. The data was taken by conducting listening comprehension test and filling questionnaires. The objective test was designed to collect the data about the students' problems in listening. The listening test that was given to the third semester students of English language education department, UST was taken from "How to Prepare the TOEFL" by Morphy Baron (1985). The test consisted of statements, dialogues, short and long stories. Meanwhile, the questionnaire was about the students' learning problems in listening III that is used to investigate a certain alternative strategies that could use to solve the problems in the teaching of listening. The questionnaire was based on the Micro-Skills of Listening (Brown, 2001:256).

The population of this study included the third semester English language education department students of Sarjanawiyata Tamansiswa University in academic year 2006/2007. The data used random sampling technique to get the sample of this study. The sample were 26 students. The techniques of data analysis were used to describe and investigate the correlation between the students' learning problems in listening III and their achievements. The inferential correlation analysis was utilized to provide the information about the correlation between the students' learning problems in listening III and their achievements to provide 
alternative solutions in the teaching and learning of listening process in the classroom. This study used Product Moment Correlation formula after the analysis the normality and the linearity were processed.

The result showed that most of the listening problems of the students include:

1. Lack of vocabulary mastery

2. Less understanding grammatical forms, speakers' utterances, unclear pronunciation and speed of speech, unclear contents of the passages, and physical setting including uncomfortable class.

3. Lack of facility and background noise.

As the impact, some students had low motivation in learning and it affects their achievement. The scores of the students' learning problems in listening III and their achievements by using questionnaire and listening comprehension tests indicated that the students' listening learning problems were at the low level and their listening comprehension test scores showing their achievements were in moderate level. The result was shown in the table below:

Table 1. Score Listening Comprehension Test and Questionnaire

\begin{tabular}{|l|c|c|}
\hline \multirow{2}{*}{} & \multicolumn{2}{|c|}{ SCORES } \\
\cline { 2 - 3 } & $\begin{array}{c}\text { Listening } \\
\text { Comprehension } \\
\text { Test }\end{array}$ & Questionnaire \\
\hline Student 1 & 56.67 & 89.71 \\
\hline Student 2 & $\mathbf{2 0 . 0 0}$ & 81.71 \\
\hline Student 3 & 26.67 & 79.43 \\
\hline Student 4 & 33.33 & $\mathbf{9 4 . 8 6}$ \\
\hline Student 5 & 56.67 & 72.57 \\
\hline Student 6 & 40.00 & $\mathbf{6 7 . 4 3}$ \\
\hline Student 7 & 40.00 & 77.71 \\
\hline Student 8 & 33.33 & 72.57 \\
\hline Student 9 & 40.00 & 68.57 \\
\hline Student 10 & 33.33 & 81.14 \\
\hline Student 11 & 30.00 & 72.57 \\
\hline Student 12 & 33.33 & 81.71 \\
\hline Student 13 & 50.00 & 74.86 \\
\hline Student 14 & 60.00 & 73.14 \\
\hline Student 15 & 46.67 & 76.00 \\
\hline
\end{tabular}




\begin{tabular}{|l|l|l|}
\hline Student 16 & 33.33 & 80.00 \\
\hline Student 17 & 36.67 & 79.43 \\
\hline Student 18 & 60.00 & 78.29 \\
\hline Student 19 & 50.00 & 76.57 \\
\hline Student 20 & 46.67 & 78.86 \\
\hline Student 21 & 50.00 & 75.43 \\
\hline Student 22 & 30.00 & 70.29 \\
\hline Student 23 & $\mathbf{6 3 . 3 3}$ & 82.29 \\
\hline Student 24 & 36.67 & 78.29 \\
\hline Student 25 & 46.67 & 78.86 \\
\hline Student 26 & 40.00 & 74.29 \\
\hline
\end{tabular}

The result of the analysis stated that "there is a positive and significant correlation between the students' learning problems in Listening III and their achievements."

\section{Strategies to Overcome the Problems}

In listening activities, the students need to pay attention, concentration and focus on the native speaker's utterances that were presented by the teacher or using a tape recorder. Listening activities require an understanding of phonetics (pronunciation) and vocabulary mastery. The students also need to understand grammatical forms that can speed up their language learning activities. The knowledge of grammar can help the students comprehend some ways of using language more effectively.

Listening can be learnt from elementary up to advanced level. At university level, listening can be learnt from the first up to forth semesters. The lecturer has to encourage them by selecting and presenting interesting listening materials. The lecturer has to apply certain alternative strategies and give some exercises that can measure their ability and motivate the students in learning listening. Providing the high quality of facility and media can improve the students' willingness to learn listening.

The lecturer has to develop and improve the techniques and strategies in the teaching of listening, for instance:

1. Preparing a tape recorder and selecting the various appropriate listening materials to be given to the students.

2. Establishing a positive interaction between the teacher and students. 
3. Giving a clear instruction and explanation and giving an opportunity to use dictionary.

4. Making an interesting atmosphere in listening activity and improving the right and various techniques that can motivate the students as listeners in order to make them more comfortable in learning listening materials.

5. Introducing the real use of spoken English in classroom and asking the students to have a real English conversation.

6. Sending real native speaker and recorded materials to provide opportunities for the students to listen to the native speaker's voice.

\section{CONCLUSION}

Based on the research findings and discussions in the previous chapter, the writer tries to make some conclusions as follows:

1. Listening is an important skill and a basic skill in language learning. Without an effective listening skill, learners will not be able to learn to communicate effectively. The students have some problems in comprehending the speech of the native speaker. The lack in contextual knowledge is an obstruction in listening comprehension activity.

2. Listening skills are developed through three elements. They are access to words, parsing, memory and cognitive. The listening process can be divided into two classifications of approaches. They are bottom up and top down approach. The selection of the materials has to comply with the students' level, and the exercises must be able to measure the students' ability. A new style in teaching listening in the class should be appropriate with the stages or the principles of a listening lesson (Pre-listening, while-listening, and postlistening) that can motivate the students in learning listening.

3. Successful teaching of listening depends on the techniques that are used in teaching methods. So, the teacher has to apply an appropriate technique that can make the students more interested in listening activity. The key of interest in listening is an important factor to make the students pay attention to the materials. The teacher should not give exercises or tasks provided in textbooks without thinking about whether they are suitable for the students or not. The strategy that can be applied by the students is how to make them motivated in learning listening. 
4. In this research, the writer investigated two variables. They are the students' problems in listening III and the students' achievements. So, based on the findings and discussions above, she could conclude that there is a positive and significant correlation between the students' learning problems in Listening III and their achievements.

\section{REFERENCES}

Brown, H. Douglas. (2001). Teaching by Principles: An Interactive Approach to Language Pedagogy. San Francisco: Second Edition Longman.

Burhan, Y. (1971). Problema Bahasa dan Pengajaran Bahasa Indonesia. Bandung: Ganesa.

Byrne. (1981). Learning Theory: Instructional Theory Psycho Educational Design. NewYork: Mc. Grawhill Book, Co.

Cook, Vivian. (2001). Second Language Learning and Language Teaching. London: Arnold.

Howatt, A. and J. Dakin. (1974). Language Laboratory Material, Techniques in Applied Linguistics London: Oxford University Press..

Krashen, S., and T. Terrel. (1983). The Natural Approach: Language Acquisition in the Classroom. Oxford: Pergamon.

Widdowson, H.G. (1978). Teaching Language as Communication. New York: Oxford University Press.

Yagang, Fan. (1993). Listening: Problems and Solutions. The United States: The English Teaching Forum. 